\title{
Linking climate change and progressive eutrophication to incidents of clustered animal mortalities in different geographical regions of South Africa
}

\author{
P. J. Oberholster ${ }^{1 \star}$, A-M. Botha ${ }^{2}$ and J. G. Myburgh ${ }^{3}$ \\ ${ }^{1}$ CSIR Natural Resources and the Environment, P. O. Box 395, Pretoria, ZA0001, South Africa. \\ ${ }^{2}$ Department of Genetics, University of Pretoria, Hillcrest, Pretoria, South Africa, ZA0001, South Africa. \\ ${ }^{3}$ Department of Paraclinical Sciences, Faculty of Veterinary Science, University of Pretoria, P/Bag X04, Onderstepoort \\ ZA0110, South Africa.
}

Accepted 17 September, 2009

\begin{abstract}
Cyanobacterial blooms have become an increasing problem in South African freshwater bodies. Since certain species of cyanobacteria are well-known for biosynthesis of potent hepatic and neurotoxins, such blooms can pose a significant threat to the health of animals and humans. The massive proliferation of these organisms in rivers and lakes is largely due to progressive eutrophication. However, a warming trend in the Southern hemisphere, indicated by a threefold increase in the minimum temperature compared to maximum temperature between 1950 and 1990, is likely the cause of the increasing occurrence of toxic cyanobacterial bloom forming species, previously hampered by low water temperatures in different geographical regions of South Africa.
\end{abstract}

Keywords: Climate change, eutrophication, cyanobacterial blooms, animal mortalities, seasonal cycles.

\section{INTRODUCTION}

Eutrophication and climate change are two key pressures impacting on lake ecosystems' structure and function. According to the Intergovernmental Panel on Climate Change IPCC (2007), current trends of climate change could lead to an average global temperature increase of $2-3^{\circ} \mathrm{C}$ within the next fifty years. A $2^{\circ} \mathrm{C}$ increase can lead to a $20-30 \%$ decrease in water availability in some vulnerable regions, such as southern Africa and the Mediterranean. Clark (2006) estimated that runoff from rivers on the west and south coasts of South Africa would decline by $11-84 \%$, while those on the east coast would generally decline by $2-21 \%$ (with decreases of $2-10 \%$ at St Lucia and Mtata estuaries) due to an increase in air temperature.

Climate affects lake physics (temperature, mixing), chemistry (DOC, pH, nutrients) and biological processes both directly and indirectly. This can accelerate the

\footnotetext{
${ }^{*}$ Corresponding author. E-mail: poberholster@csir.co.za.
}

eutrophication process (Carvalho and Kirika, 2003) e.g. phosphorus recycling (number of phosphorus molecules recycled per unit time) is more intensive in warmer waters, while processes of phosphorus release from lake sediment and mineralization are highly temperature dependent (Hamilton et al., 2001). Howard and Easthope (2002) predicted that the close relationship between water temperature and growth rate of cyanobacteria may be affected due to climate change. Monthly means of daily maximum and minimum temperatures for over $10 \%$ of the southern hemisphere landmass indicate that an increase of minimum temperature has occurred at a rate three times that of the maximum temperature during the period $1950-1990\left(0.84^{\circ} \mathrm{C}\right.$ versus $\left.0.28^{\circ} \mathrm{C}\right)$ (Karl et al., 1993). While climate change can be described as changes to temperature averages, the more significant impacts will be due to increased variability of climatic conditions. These changes will create favourable conditions for cyanobacterial bloom formation extending much beyond the conventional seasonal cycles (Paerl and Huisman, 2008). Furthermore, these conditions are 
becoming increasingly unpredictable, which calls for effective early warning systems and risk management strategies.

Eutrophication is generally indicated by accumulation of metabolic products (e.g. hydrogen sulphide in deep waters), discolouration (low Secchi depth), deterioration in the taste of water, dissolved oxygen depletion and an enhanced occurrence of cyanobacterial bloom forming species (Oberholster et al., 2009a,b). Although eutrophication is a natural slow ageing process of lakes, it can be greatly accelerated by human intervention in the natural biogeochemical cycling of nutrients within a watershed (Rast and Thornton, 1996). In South Africa most drinking water comes from surface waters, where cyanobacteria have been recorded in many, if not most instances (Oberholster et al., 2004). The excessive development of cyanobacterial blooms is often the main symptomatic of uncontrolled eutrophication. Due to climatic conditions and excessive nutrient loads from agriculture and discharge of treated sewage, Microcystis and Anabaena cyanobacterial genera often dominate the phytoplankton of reservoirs and rivers in the central and northern regions of South Africa (Van Ginkel, 2004). The most alarming characteristic of cyanobacteria is the ability of many species to produce a range of extremely potent low-molecular-weight cyanotoxins. These cyanotoxins are grouped according to the target physiological systems, organs, tissues, or cells. Cyanotoxins that affect the nervous system are called neurotoxins, while heaptotoxins breakdown liver cell integrity. Cytotoxins cause necrosis and damage genetic material while lipopolysaccharide (LPS) endotoxins can cause inflammation, septic shock and liver damage (Sivonen and Jones, 1999).

Lipopolysaccharide (LPS) endotoxins are widely produced by cyanobacteria and are an obligate part of the outer cell layer of cyanobacteria. LPS may contribute to inflammatory and gastrointestinal incidents and are recognized to cause fever in mammals and to be involved in septic shock syndrome, which may aggravate toxicantinduced liver injury (Choi and Kim, 1998; Codd, 2000).

Concerns over the health risks to humans by these cyanotoxins, have prompted the World Health Organization (WHO) to adopt a provisional guideline value

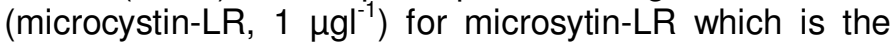
most common variant of microcystins in drinking water (WHO, 1998). Due to the lack of reliable data, no guideline value is yet set for concentrations of nodularin or cylindrospermopsin toxins. In the case of South Africa there are guidelines for cyanotoxins in domestic water (only for microcystins) but values are not specified for drinking water guidelines or national drinking water standards (DWAF, 1996). The aim of this study was to investigate if there is an increase in trends of toxic cyanobacterial bloom incidences in different geographical regions of South African since 1990 and whether this scenario could be related to climate change and eutrophication.

\section{INCREASE IN POISONING INCIDENCES FROM CYANOBATERIAL BLOOMS IN DIFFERENT GEOGRAPHIC REGIONS OF SOUTH AFRICA}

Although blooms of cyanobacteria are common in South Africa, animal deaths due to hepatotoxins were largely confined to the central and northern Provinces of South Africa prior to 1994 (Scott, 1987) (Figure 1). This pattern changed since 1994, when the first south-western Cape, poisonings occurred in the Malmesbury-Darling region. In both cases livestock losses ( 3 cattle plus 5 exhibiting photosensitivity and 29 sheep) occurred. Filaments of Nodularia spumigena were found in the drinking water supplies in both incidents. Poisoning by this species had not been recorded previously in water bodies of the area (Van Halderen et al., 1995). Numerous incidences followed, of which the Kareedouw incident was the worst, with the massive live stock loss of 290 in milk dairy cows. A further 70 animals were diagnosed with photosensitivity and had to be slaughtered. Although the clinical signs and symptoms were consistent with acute hepatotoxicosis, microscopic examination of the rumen contents of two of the dead animals revealed the presence of filaments of Anabaena sp. Also, a mat of Oscillatoria sp. filaments was found growing on the wall of the cement-lined reservoir from which the animals had drunk. This was the first incident related to poisoning of Oscillatoria sp. in the southern and south-western regions of the country (Harding and Paxton, 2001) (Figure 1). In 2000, the first incidence of fish kills by a bloom of mixed species (Cylindrospermopsis raciborskii, Anabaena sp. and Oscillatoria sp.) in the Orange River system downstream of the confluence with the Harts River in the Northern Cape Province of South Africa was reported. This was also the first report on the occurrence of a bloom of Cylindrospermopsis sp. in South Africa (Harding and Paxton, 2001) and is of particular concern from a water quality perspective, due to its known ability to produce a potent hepatotoxic alkaloid cylindrospermopsin (Saker et al., 2003) and the neurotoxic PSP toxin (paralytic shellfish poisoning) (Harding and Paxton, 2001). This freshwater cyanobacteria of tropical origin, is not only increasingly found in sub-tropical water bodies, but also in temperate regions (Figure 1).

Moreover, during 2005 rangers of the Kruger National Park, South Africa found several carcasses in the region of Lake Nhlanganzwane that is situated in the extreme south eastern area of the Kruger National Park. The cause of death of these animals could not be determined, due to the decomposed state of the carcasses. After the discovery of a fresh zebra carcass, a full range of clinical tests were conducted by the State Veterinary Services and the reason of mortality was ascribed to cyanobacterial intoxification from a bloom of Microcystis 


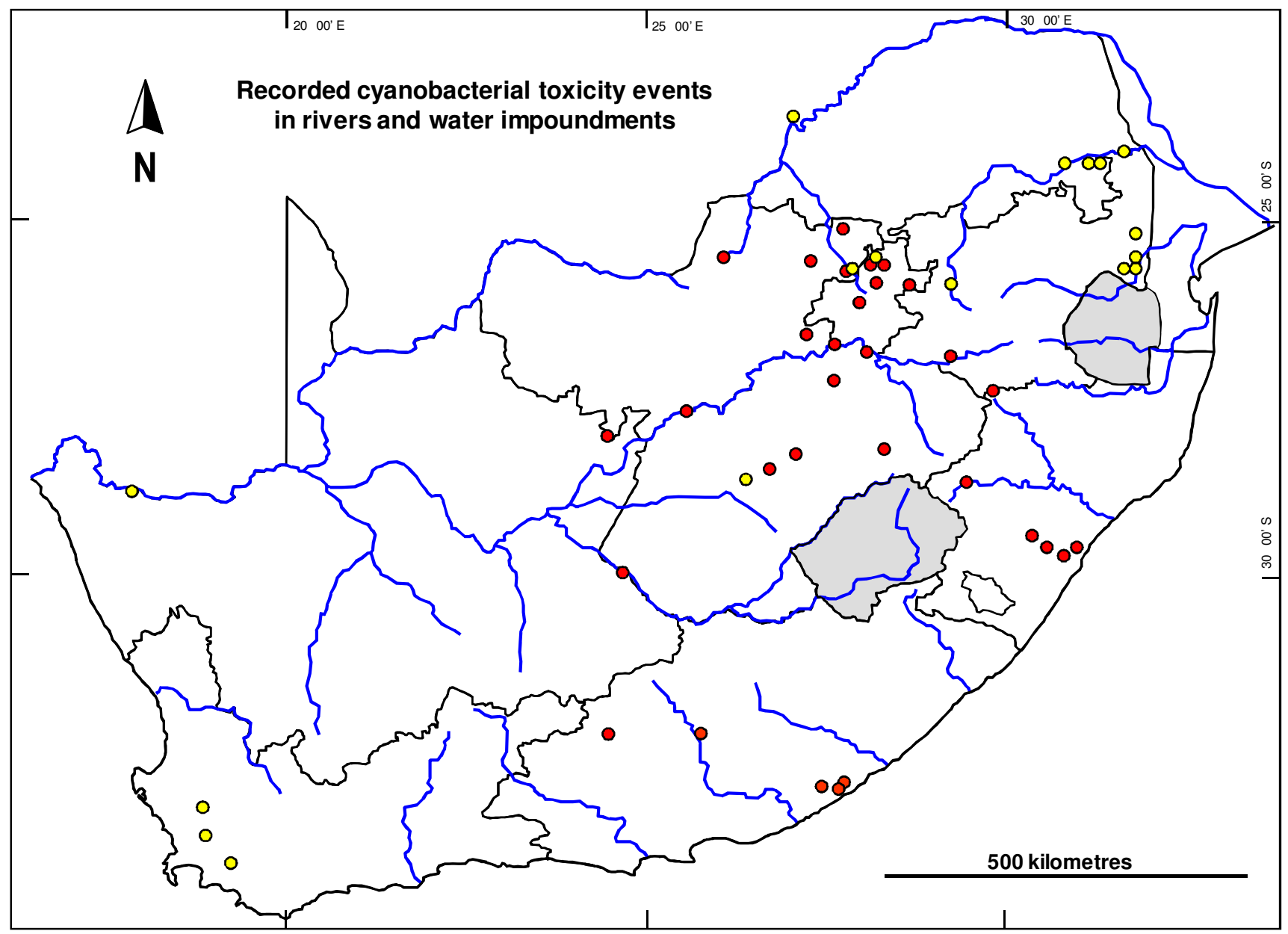

Figure 1. The distribution of recorded cyanobacterial toxicity events in South African water supply impoundments and rivers before 1990 ( $\mathrm{O}=$ red dots) and after 1990 ( $\mathrm{O}=$ yellow dots), which caused the death of livestock, wildlife or domestic animals.

aeruginosa that occurred in Lake Nhlanganzwane. The average surface water temperature of the lake during the intoxification incident was $20^{\circ} \mathrm{C}$. A total of 52 carcasses were detected during the winter month of July 2005 and these amounted to 7 white rhinoceros, 2 lions, 2 cheetahs, 9 zebras, 23 wildebeest, 1 hippopotamus, 1 giraffe, 5 buffalo, 1 warthog and 1 Kudu. Two years later, in June 2007, mortalities of white rhinoceros, zebras and wildebeest (22 carcasses) were again discovered in the area of Lake Nhlanganzwane. During this period of animal intoxification the surface water temperature of Lake Nhlanganzwane was between 19 to $21^{\circ} \mathrm{C}$. Although previous reports of animal mortalities had occurred in this geographical region during summer time, this incidence represented the first reports in mid winter (Oberholster et al., 2009b) (Figure 1).

In addition, during the onset of autumn March, 2008, Lake Loskop in the Mpumalanga province of South Africa experience it's first ever massive Microcystis sp. bloom since the construction of the impoundment in 1937. Mortalities of fish were reported within the Loskop Nature
Reserve during the time of the bloom. This mixed bloom of Microcystis aeruginosa and Microcystis flos-aquae contained a maximum cell concentration of $2.2 \times 10^{7}$ cells/l in April when chl a concentrations increased up to $196 \mu \mathrm{g} / \mathrm{l}$ while surface water temperatures ranged between 21 and $22^{\circ} \mathrm{C}$. Moreover, the occurrence of a bloom of the filamentous cyanobacteria Oscillatoria sp. in the Tuli block on the border between Botswana and South Africa in mid winter July 2008 caused mortalities of more than 70 Bushbuck and Impalas over a period of one month. This incidence also represent the first ever report of bloom formation and intoxification of animals from this particular cyanobacterial species in this geographical region (Figure 1).

\section{CLIMATE CHANGE AND CYANOBACTERIAL BLOOMS}

Strong evidence exists for a widespread decrease in the diurnal temperature range (DTR) over the past several 
Table 1. Trends of South Africa's temperature (1951 - 1990) for annual and three month mean maximum (Max), minimum (Min), as well as diurnal temperature (DTR) based on a weight average of 12 meteorological data stations, modified after Karl et al. (1993).

\begin{tabular}{|l|c|c|c|}
\hline \multicolumn{1}{|c|}{ Seasons } & $\operatorname{Max}\left({ }^{\circ} \mathbf{C}\right)$ & $\operatorname{Min}\left({ }^{\circ} \mathbf{C}\right)$ & $\operatorname{DTR}\left({ }^{\circ} \mathbf{C}\right)$ \\
\hline December, January, February & 0.8 & 2.0 & -1.2 \\
March, April, May & 2.2 & 1.7 & 0.5 \\
June, July, August & 1.3 & 1.3 & 0.0 \\
September, October, November & -0.7 & 1.8 & -2.4 \\
Annual trends & 0.9 & 1.7 & -0.8 \\
\hline
\end{tabular}

decades in many regions of the globe. The mean monthly DTR is defined as the monthly mean of the difference between the maximum and minimum daily temperatures. Analysis by Karl et al. (1993) indicates that strong evidence exists for a decrease of DTR (1952 - 1990) during the months September, October and November ($2.4^{\circ} \mathrm{C}$ ) as well as for the months December, January and February $\left(-1.2^{\circ} \mathrm{C}\right)$ for the region of South Africa (Table 1). Furthermore, the data indicates that the decrease of the DTR range is approximately equal to the increase of the mean temperature, which signifies that the gap between maximum and minimum temperatures for the months September, October and November is decreasing, while the monthly minimum temperature is increasing. This increase in daily temperatures will imply, that in the future, peak cell concentrations of cyanobacterial blooms which occurred in the summer months (November, December and January) of South Africa will start developing three months earlier in spring, depending on the surface water temperature, species diversity and environmental conditions of lakes e.g. TP:TN ratio as observed by Oberholster and Botha (2007). A earlier study (1982-1983) conducted by Robarts and Zohary (1984) on Lake Hartbeespoort, showed that the M. aeruginosa population represented between 70 and $90 \%$ of the total phytoplankton assemblage in the winter months June and July and was replaced by the diatom Melosira granulata as the dominant population in August 1982 (Figure 2). In a two year study (2005 - 2006) conducted by Oberholster and co-worker on Lake Hartbeespoort, South Africa which is known as the most productive lake on record (Kalff, 2001) they observed that the phytoplankton community structure was dominated during the summer months by the cyanobacterial species $M$. aeruginosa $(90 \%)$ followed by the filamentous cyanobacteria Oscillatoria sp. (4\%) and Pseudoanabeana (3\%). In July 2005 and 2006 (midwinter), average surface water temperature was $13.7^{\circ} \mathrm{C}$ while the total percentage of phytoplankton assemblage consist of $70 \%$ of $M$. aeruginosa, $1 \%$ of Oscillatoria, $2 \%$ of Pseudoanabeana and the remaining $21 \%$ consist of the diatom sp. M. granulata. However, in August (late winter beginning of spring) 2005 and 2006 the diatom M. granulata population declined to $9 \%$ of the total phytoplankton assemblage, while the $M$. aeruginosa population increased to $79 \%$ at a average surface water temperature of $15.7^{\circ} \mathrm{C}$ (Figure 2). Moreover, a positive correlation ( $p \leq 0.05, r=0.9175$ ) between the percentage increase in cyanobacteria $M$. aeruginosa population in August 2005 and 2006 and the higher surface water temperature during the same period of time was observed. Low average concentrations of total microcystin-LR $(0.37 \mu \mathrm{g} / \mathrm{l})$ were also recorded during July 2005 and 2006 at an average surface water temperature of $13.7^{\circ} \mathrm{C}$. Hence, the total average microcystin-LR levels increased to a average of $678 \mu \mathrm{g} / \mathrm{l}$ in November 2005 and 2006 coinciding with the increase in average surface water temperature $\left(25.1^{\circ} \mathrm{C}\right)$ for this month over the two year study period. A strong positive correlation ( $p$ $\leq 0.05, r=0.9201$ ) between the increase in surface water temperature and the increase in total cyanobacteria Microcystis in Lake Hartbeespoort was observed during their study. This phenomenon indicates that cyanobacteria respond more strongly to possible rising temperatures in late winter beginning of spring, resulting in higher growth rates in a warming climate (Paerl and Huisman, 2008). Theoretically such increase in winter surface water temperature could favour cyanobacterial dominance, since several cyanobacterial taxa appear to perform well at higher temperatures compare to other phytoplankton taxa (De Senerpont Domis et al., 2007). This change, which causes earlier algal spring bloom formation, was also observed in time series analysis of lakes in north Western Europe by Gerten and Adrian (2000). Although diatoms (Bacillariophyceae) tend to be abundant in the mixed water period of spring as observed by Robarts and Zohary (1984) in Lake Hartbeespoort, it seems from data generated by Oberholster and coworkers in their study on Lake Hartbeespoort during 2005 - 2006, that this seasonal phenomena has changed. Although, Moss et al. (2003) indicated that phytoplankton crop also appears to be controlled extensively by nutrient availability it is most unlikely that the switch from a diatom to a dominant cyanobacterial lake system in August 2005 and 2006 was due to nutrient availability. It is known that diatoms in eutrophic water, like in the case of Lake Hartbeespoort, can be inhibited by a low supply of silica, this was however not applicable to Lake Hartbeespoort. Willen (1991) found in his study that concentrations as 


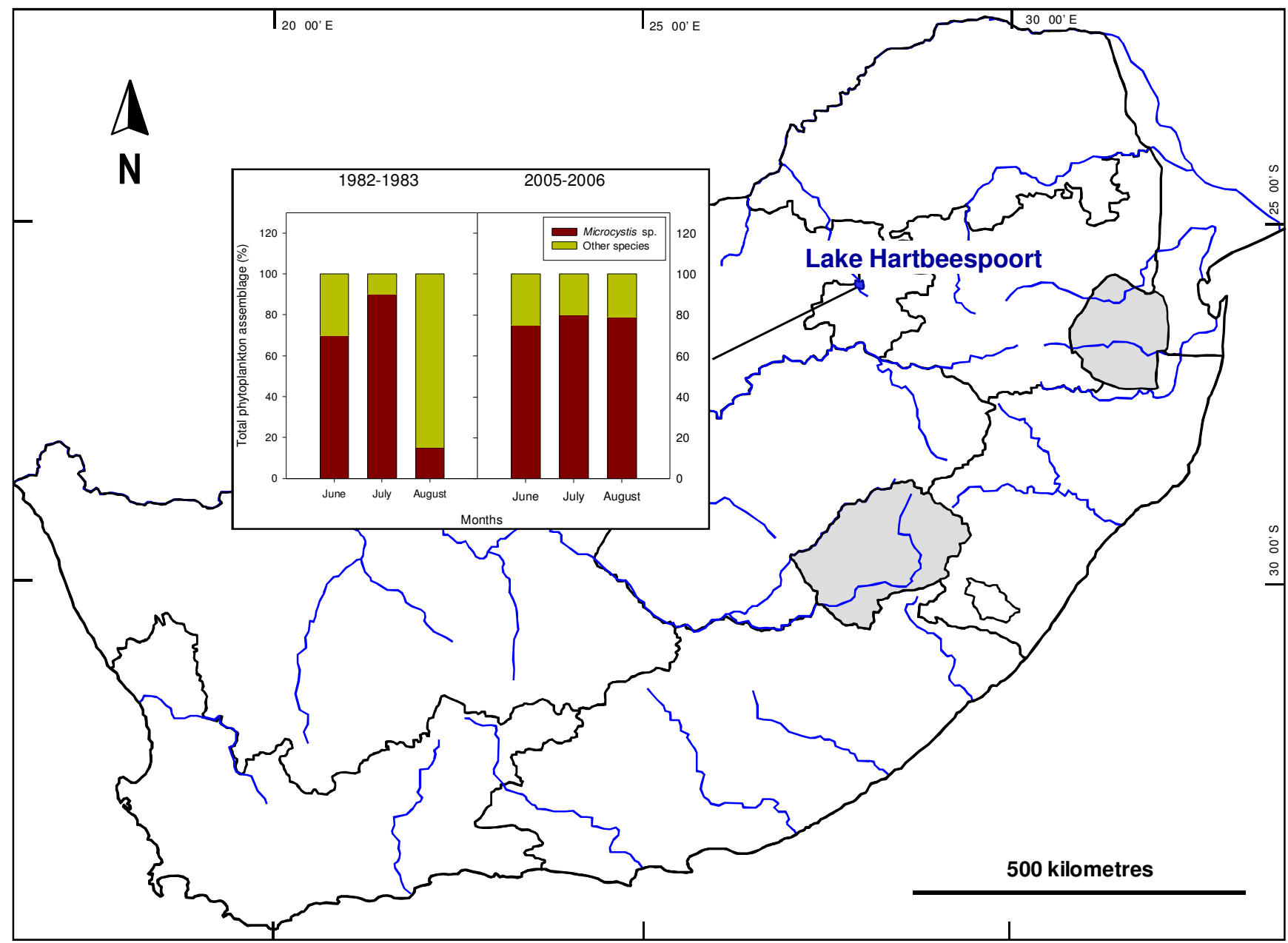

Figure 2. A comparison between historical data of Lake Hartbeespoort of the total phytoplankton assemblage for the months June, July and August 1982 - 1983 and this study (2005 - 2006) which indicate a extended growing season for M. aeruginosa as well as an early spring bloom formation.

low as $0.2 \mathrm{mg} / \mathrm{l}$ - much less (average silica in Lake Hartbeespoort, $3.1 \mathrm{mg} / \mathrm{l}$ ) than was measured in August 2005 and 2006 was sufficient for diatom production.

\section{EFFECTS OF SURFACE WATER TEMPERATURE ON CYANOBACTERIAL BLOOMS IN DIFFERENT GEOGRAPHIC REGIONS OF SOUTH AFRICA}

The effects of temperature on the rates of biological processes are well known, but the occurrence of particular phytoplankton species due to climate change is still relative uncertain. Cyanobacterial blooms usually occur during warm periods, at temperatures above $20^{\circ} \mathrm{C}$ (Robarts and Zohary, 1987). Response to temperature varies among cyanobacterial genera and strains (Table 2). Microcystis sp. has been observed to be more temperature sensitive in comparison to Anabaena, Aphanizomenon and Planktothrix spp. (Robarts and Zohary, 1987; Schreurs, 1992; Oliver and Ganf, 2000) and its growth was found to decline sharply at temperatures below $15^{\circ} \mathrm{C}$ (Robarts and Zohary, 1987). Kruger and Eloff (1978) found a correlation between the surface water temperature and the development of Microcystis blooms in eutrophic impoundments in South Africa. They reported that Microcystis blooms started to develop in open lake water, once water temperatures reach $16-17^{\circ} \mathrm{C}$. Their results showed that the effect of temperature on specific growth rate occurs after the upper temperature limit is surpassed. From their observations Kruger and Eloff (1978) suggested that the low surface water temperatures in the South African Highveld impoundments in winter $\left(7-8^{\circ} \mathrm{C}\right)$ may be a barrier to growth of bloom forming cyanobacterial species. However, from the observations by Botha and Oberholster (2007) it was clear that the average minimum surface water temperature of selective impoundments in the Highveld region of South Africa was much higher (average $13^{\circ} \mathrm{C}$ ) than indicated by Kruger and Eloff (1978) in their earlier study.

Climate changes and the consequent increase in the 
Table 2. Temperature optima $\left(\mathrm{T}_{\mathrm{opt}},{ }^{\circ} \mathrm{C}\right)$ for cyanobacterial growth at which the maximum growth rate was observed and minimum temperature $\left(\mathrm{T}_{\min },{ }^{\circ} \mathrm{C}\right)$ at which growth ceased in laboratory cultures of various cyanobacterial species that dominate South African freshwater impoundments.

\begin{tabular}{|l|l|l|l|}
\hline Dominant species & \multicolumn{1}{|c|}{$\mathbf{T}_{\min }\left({ }^{\circ} \mathbf{C}\right)$} & \multicolumn{1}{|c|}{$\mathbf{T}_{\text {opt }}\left({ }^{\circ} \mathrm{C}\right)$} & \multicolumn{1}{|c|}{ Reference } \\
\hline M. aeruginosa & $10.5-13.3$ & $28.8-30.5$ & Kruger and Eloff, 1978. \\
M. aeruginosa & 10 & 30 & Nicklisch and Kohl, 1983; Butterwick et al., 2005. \\
A. variabilis & $<10$ & 30 & Collins and Boylen, 1982; Butterwick et al., 2005. \\
A. flos-aquae & 5 & 35 & Uehlinger 1981; Butterwick et al., 2005. \\
O. agardhii & $<12$ & $23-25$ & Ahlgren, 1978; Coles and Jones, 2000. \\
C. raciborskii & 15 & 30 & Briand et al., 2004. \\
\hline
\end{tabular}

minimum surface water temperatures in South African impoundments, can bring about the development of a distinct water temperature gradient earlier in the year (late winter and spring), when the warm upper water layer and cooler bottom layers result in a physically-stable (stratified) water body, favouring the growth of various toxic bloom forming cyanobacterial species. These species would have been previously hampered by low minimum water temperature in the surface layer. An increase in spring water temperatures could also be related to the germination of Cylindrospermopsis raciborskii akinetes which allow the species to survive during cold months and only germinate when temperature of water or sediment reaches $22-23^{\circ} \mathrm{C}$ (Padisak 1997). Furthermore, cyanobacteria have generally higher temperature optima for growth, photosynthesis and respiration than green algae and diatoms (Robarts and Zohary, 1987).

Temperature changes were also found to induce variations in both the concentration and peptide composition of the cyanobacterial toxin (Yokoyama and Park, 2003). The study by Wicks and Thiel (1990) on environmental factors that affect the production of microcystins in M. aeruginosa scum in Lake Hartbeespoort (South Africa) confirmed that microcystins were either not detectable or occurred at very low concentrations during the winter months (May to August). Furthermore, Van der Westhuizen and Eloff (1985) found in their study that the $M$. aeruginosa strain UV-006 was twice as toxic when cultured at $20^{\circ} \mathrm{C}\left(\mathrm{LD}_{50} 25.4 \mathrm{mg} / \mathrm{kg}\right)$ than at $32^{\circ} \mathrm{C}$, but at $16^{\circ} \mathrm{C}$ the toxicity was reduced by $35 \%$ compared to $20^{\circ} \mathrm{C}$. This is in line with the study of Oberholster and co-worker on Lake Hartbeespoort that showed low toxic concentrations of microcystins in the winter months June to July 2005 and 2006. This is also comparable with results obtained from a study by Oberholster and Botha (2007) on Lake Midmar in South Africa where low detectable levels of microcystin-LR varying from 0.09 to $0.17 \mu^{-1}{ }^{-1}$ occurred during the cold winter months, in spite of the presence of a high cyanobacterial biomass, indicating that different temperatures has a pronounced effect on the toxicity of cyanobacterial blooms. Oberholster et al. $(2006 a, b)$ demonstrated that the transcript of the mcy genes coding for subunits of the microcystin synthetase in $M$. aeruginosa was expressed at much higher levels during summer $\left(23^{\circ} \mathrm{C}\right)$, than in winter $\left(4^{\circ} \mathrm{C}\right)$, in Lake Sheldon, Colorado, using real time-PCR technologies.

In addition, long-term historical data on animal mortalities in South Africa due to cyanobacterial intoxification by Oberholster et al. (2005) when compared to new reported incidences, also showed an increase in toxics bloom appearance during winter months. The recent occurrence of toxic blooms of cyanobacterial species, previously not reported from many different geographical regions in South Africa over the period from 1913 to 1994, also indicates possible bloom formation of these species which were previously hamper by low surface water temperatures. Although Janse van Vuuren and Kriel (2008) indicated that $C$. raciborskii was first detected in South Africa during 2000 in the lower reaches of the Orange River, a previous report on this species in Lake Rhenosterkop does exist (Scott, 1987), however, no bloom formation or intoxification incidence related to this species was reported predated 2000. A possible explanation for the bloom formation of $C$. raciborskii in the lower Orange River is the similarity with prevailing environmental conditions like in the case of the Fitzroy River, Australia (Bormans et al., 2004). The stream flow of the Orange River system is extremely erratic and floods are rapid in summer time containing high silt loads (Davies and Walker, 1986). This lead to slow clearing, allowing the load of incoming nutrients to be removed before light climate conditions is favourable for phytoplankton growth (Bormans et al., 2004). Briand et al. (2004) suggests that the colonization of the mid-latitudes by $C$. raciborskii may result from a combination of its ability to tolerate a rather wide range of climatic conditions and the global warming phenomenon. These conditions provide this species with better environmental conditions for its growth since an increase in spring temperatures, could induce germination of akinetes and growth earlier in the season. This leads to a competitive advantage for $C$. raciborskii over other temperate phytoplankton species (Briand et al., 2002).

\section{Conclusion}

In line with our results which highlight a potential shift in 
certain phytoplankton communities against a background of eutrophication, the authors predict an increase in blooms of cyanophytes and poisoning incidences by previously non dominant species in different geographical climatic regions of South Africa in the near future, if the current trends in climate change continue. This is due to cyanobacterial preference for higher surface water temperature ranges. In addition, the occurrence of cyanobacteria species that have previously been hampered to form blooms due to low temperature and nutrient concentrations, may form mix blooms with existing species which potentially can lead to the simultaneous occurrence of both neuro and hepatic biotoxins in one bloom.

\section{REFERENCES}

Ahlgren G (1978). Growth of Oscillatoria agardhii in chemostat culture. Dependence of growth constants on temperature. Mitteilungen der internationalen Vereinigung für theoretische und angewandte Limnologie 21: 88-102

Bormans M, Ford PW, Fabbro L, Hancock G (2004). Onset and persistence of cyanobacterial blooms in a large impounded tropical river, Australia. Marine Freshwater Res. 55: 1-15

Botha AM, Oberholster PJ (2007). PCR based markers for detection and identification of toxic cyanobacteria. Water Res. Commission Report No. K5/1502/01/07, Pretoria, ZA.

Briand JF, Leboulanger C, Humbert JF (2004). Cylindrospermopsis raciborskii (cyanobacteria) invasion at mid-latitudes: selection, wide physiological tolerance, or global warming? J. Phycol. 40: 231-238.

Briand JF, Robillot C, Quiblier L (2002). Environmental context of Cylindrospermopsis raciborskii (Cyanobacteria) blooms in a shallow pond in France. Water Res. 36: 3183-3192.

Butterwick C, Heaney SI, Talling JF (2005). Diversity in the growth rates of freshwater algae and its ecological relevance. Freshwater Biol. 50: 291-300.

Carvalho L, Kirika A (2003). Changes in shallow lake functioning to climate changes and nutrient reduction. Hydrobiologia 506: 789-796.

Choi SH, Kim SG (1998). Lipopolysaccharide inhibition of rat hepatic microsomal epoxide hydrolase and glutathione S-transferase gene expression irrespective of nuclear factor-kB activation. Biochem. Pharmacol. 56: 1427-1436.

Clark BM (2006). Climate change: A looming challenge for fisheries management in southern Africa. Marine Policy, 30: 84-95.

Codd GA (2000). Cyanobacterial toxins, the perception of water quality and the prioritization of eutrophication control. Ecol. Eng. 16: 51-60.

Coles JF, Jones RC (2000). Effect of temperature on photosynthesislight response and growth of four phytoplankton species isolated from a tidal freshwater river. J. Phycol. 36: 7-16.

Collins CD, Boylen CW (1982). Physiological responses of Anabaena variabilis (Cyanophyceae) to instantaneous exposure to various combinations of light intensity and temperature. J. Phycol. 18: 206211.

Davies BR, Walker KF (1986). The ecology of river systems. Dr W Junk Publishers, Boston, USA, pp. 123-141.

De Senerpont Domis LN, Mooij WM, Huisman J (2007). Climateinduced shifts in an experimental phytoplankton community: a mechanistic approach. Hydrobiologia 584: 403-413.

DWAF (Department of Water Affairs and Forestry) (1996). South African Water Quality Guidelines (second addition). Volume 1: Domestic Use, Pretoria, South Africa.

Gerten D, Adriaan R (2000). Climate-driven changes in spring plankton dynamic and the sensitivity of shallow polymictic lakes to the North Atlantic Oscillation. Limnol. Oceanogr. 45: 1058-1066.

Hamilton DP, Spillman C, Prescott KL, Kratz TK, Magnuson JJ (2001). Effects of atmospheric nutrient input on trophic status of Crystal Lake, Wisconsin. Verh. Int. Verein Limnol. 28: 467-470.

Harding WR, Paxton BR (2001). Cyanobacteria in South Africa: A
Howard A, Easthope MP (2002). Application of a model to predict cyanobacterial growth patterns in response to climatic change at Farmoor Reservoir, Oxfordshire, UK. Sci. Total Environ. Vol. 282283, pp. 459-469

IPCC (2007). Climate Change 2007: The Physical Science Basis. Contribution of Working Group I to the Fourth Assessment Report of the Intergovernmental Panel on Climate Change.

Janse van Vuuren VS, Kriel GP (2008). Cylindrospermopsis raciborskii, a toxic invasive cyanobacterium in South African fresh waters. African Journal of Aquatic Science 33: 17-26

Kalff J (2001). Limnology: Inland water ecosystems. Prentice Hall, Upper Saddle River, New Jersey, USA. pp. 531-535

Karl TR, Jones PD, Knight TC, Kukla G, Plummer N, Razuvayev V, Gallo KP, Lindseay J, Charlson RJ, Peterson TC (1993). A new perspective on recent global warming: Asymmetric Trends of Daily Maximum and Minimum Temperature. Bull. Am. Meteorol. Soc. 74: 1007-1023

Kruger GHJ, Eloff JN (1978). The effects of temperature on specific growth rate and activation energy of Microcystis and Snechococcus isolates relevant to the onset of natural blooms. J. Limnol. Soc. Southern Africa, 4: 9-20.

Moss B, McKee D, Atkinson D, Collings SE, Eaton JW, Gill AB, Harvey I, Hatton K, Heyes T, Wilson D (2003). How important is climate? Effects of warming, nutrient addition and fish on phytoplankton in shallow lake microcosms. J. Appl. Ecol. 40: 782-792.

Nicklisch A, Kohl JD (1983). Growth kinetics of Microcystis aeruginosa (Kütz.) Kütz. As a basis for modelling its population dynamics. Internationale Revue der gesamten Hydrobiologie 68: 317-326.

Oberholster PJ, Botha AM (2007). Use of PCR based technologies for risk assessment of a winter cyanobacterial bloom in Lake Midmar, South Africa. Afr. J. Biotechnol. 6: 14-21.

Oberholster PJ, Botha AM, Asthon (2009a). The influence of a toxic cyanobacterial bloom and water hydrology on algal populations and macroinvertebrate abundance in the upper littoral zone of Lake Krugersdrift, South Africa. Ecotoxicology, 18: 34-41.

Oberholster PJ, Botha AM, Cloete TE (2005). An overview of toxic freshwater cyanobacteria in South Africa with special reference to risk, impact and detection by molecular marker tools. Biochemistry, 17: 57-71.

Oberholster PJ, Botha AM, Cloete TE (2006a). Use of molecular markers as indicators for winter zooplankton grazing on toxic benthic cyanobacteria colonies in an urban Colorado lake. Harmful Algae 5: 705-716.

Oberholster PJ, Botha AM, Cloete TE (2006b). Toxic cyanobacterial blooms in a shallow, artificially mixed urban lake in Colorado, USA. Lakes \& Reservoirs: Research and Management 11: 111-123.

Oberholster PJ, Botha AM, Grobbelaar JU (2004). Microcystis aeruginosa: source of toxic microcystins in drinking water. Afr. J. Biotechnol. 3: 159-168.

Oberholster PJ, Myburgh JG, Govender D, Bengis R, Botha AM (2009b). Identification of potentially toxigenic environmental Microcystis strains after two point-source incidents of clustered wild animal mortalities in the Kruger National Park, South Africa. Ecotoxicol. Environ. Saf. 12: 1177-1182.

Oliver RL, Ganf GG (2000). Freshwater blooms. In: Whitton BA, Potts M (eds). The ecology of cyanobacteria: Their diversity in time and space. Dordrecht, Kluwer Academic Publishers, pp. 149-194.

Padisak J (1997). Cylindrospermopsis raciborskii (Woloszynska) Seenayya et Subba Raju, an expanding, highly adaptative cyanobacterium: worldwide distribution and review of its ecology. Arch. Hydrobiol. Suppl. 107: 563-593.

Paerl H, Huisman J (2008). Blooms like it hot. Science, 320: 57-58.

Rast W, Thornton JA (1996). Trends in eutrophication research and control. Hydrol. Processes, 10: 295-313. review. WRC Report No, TT 153/01, pp. 1-165.

Robarts RD, Zohary T (1987). Temperature effects on photosynthetic capasity, respiration, and growth rates of bloom-forming cyanobacteria. NZJ Mar. Freshwater Res. 21: 391-399.

Saker ML, Nogueira ICG, Vasconcelos VM, Neilan BA, Eaglesham GK, Pereira P (2003) First report and toxicological assessment of the cyanobacterium Cylindrospermopsis raciborskii from Portuguese freshwater. Ecotoxicol. Environ. Saf. 55: 243-250. 
Schreurs H (1992). Cyanobacterial dominance. Relations to eutrophication and lake morphology. PhD thesis. Amsterdam, the Netherlands, University of Amsterdam, pp. 1-198

Scott WE (1987). Toxins of blue-green algae: Ten year report. National Institute for water research, Council for Scientific and Industrial Research, Pretoria, Republic South Africa, pp. 1-186

Sivonen K, Jones G (1999). Cyanobacterial toxins, In: Chorus I, Bartram J (eds). Toxic Cyanobacteria in Water, a Guide of their Public Health Consequences, Monit. Manage. E \& FN Spon, London. pp. 41-111.

Uehlinger $U$ (1981). Experimental studies of the autecology of Aphanizomenon flos-aquae. Archiv, für Hydrobiologie, Supplement, 60: 260-288.

Van der Westhuizen AJ, Eloff JN (1985). Effect of temperature and light intensity on the toxicity of and growth of blue-green alga Microcystis aeruginosa (UV-006). Planta 163: 55-59.

Van Ginkel CE (2004). A National Survey of the Incidence of Cyanobacterial Blooms and Toxin Production in Major Impoundments. Internal Report No. N/0000/00/DEQ/0503, Resource Quality Services, Department of Water Affairs and Forestry, Pretoria, South Africa, pp. 1- 44.
Van Halderen A, Harding WR, Wessels JC (1995). Cyanobacterial (blue-green algae) poisoning of livestock in the Western Cape province of South Africa. J. S. Afr. Vet. Assoc. 66: 260-264.

WHO (1998). Cyanobacterial toxins: microcystin-LR, Guidelines for Drinking-Water Quality, World Health Organization, Geneva, Addendum to volume, pp. 95-110.

Wicks RJ, Thiel PG (1990) Environmental factors affecting the production of peptide toxins in floating scums of the cyanobacterium Microcystis aeruginosa in a hypertrophic African reservoir. Environ. Sci. Technol. 24: 1413-1418.

Willen E (1991). Planktonic diatoms-an ecological review. Algological Studies 62: 69-106. Stuttgart, Augustus 1991.

Yokoyama A, Park HD (2003). Depuration kinetics and persistence of the cyanobacterial toxin microcystin-LR in the freshwater bivalve Unio douglasiae. Environ. Toxicol. 18: 61-67. 